\title{
Impact of COVID-19 on the Yemeni
} Economy

\section{How the drop in remittances affected economic sectors, food systems, and households}

\author{
Dalia Elsabbagh, Sikandra Kurdi, and Manfred Wiebelt
}

\begin{abstract}
There has been an unprecedented decline in the flow of remittances to Yemen - a vital source of money for millions - as a result of the COVID-19 pandemic. A Social Accounting Matrix (SAM) multiplier model of Yemen's economy was used to estimate the impact of lower remittances on economic sectors and employment, food systems, and household incomes. Some of the key findings from this modeling exercise are:

- National GDP is estimated to have fallen by 8.5 percent.

- Agriculture was hardest hit, seeing an estimated drop in output of more than 9 percent. Food systems in Yemen are estimated to have experienced a reduction in output by almost 10 percent.

- Employment losses were estimated at 8 percent, mainly due to job losses in services, followed by agriculture.

- Household income fell on average by 12.5 percent, mainly driven by lower remittances but also as a result of lower factor earnings in the service sector and the agri-food system.

Options for local recovery measures are limited. Nonetheless, Saudi Arabia and other Gulf countries could enact concrete policies to help Yemeni migrant workers survive the adverse impacts of COVID-19 in their labor markets.
\end{abstract}

Since the start of the conflict in 2015, Yemen has experienced economic devastation. By the end of 2019, the loss of real GDP reached approximately 45 percent, estimated to be around 66 billion US dollars by the Yemeni Ministry of Planning (MPIC 2019). As economic activity within Yemen has stalled, remittances from Yemenis working outside the country remained a valuable and increasingly important source of income. Above and beyond the impacts of the COVID-19 pandemic inside of Yemen, the impact of the global recession on incomes earned by Yemenis abroad has the potential to have major negative consequences for the economy of Yemen.

The World Bank estimated the value of remittances to Yemen at 3.77 billion US dollars in 2019, representing around 13 percent of the Yemeni GDP, up from 10 percent in 2014 (World Bank 2021). 
The source of these remittances is primarily from Yemenis working in the Gulf region, with Saudi Arabia as the greatest contributor at about 61 percent, followed by 29 percent from other Gulf Arab countries (MPIC 2018).

Among the biggest economic consequences of the global COVID-19 pandemic for Yemen is a large drop in remittances. This can be traced to the controls and other interventions governments put in place to contain the spread of the virus. These efforts have created massive disruptions in economic activities worldwide, lowered oil prices, and decreased labor market demand in the Gulf host countries for Yemeni migrant workers. In Saudi Arabia, for example, businesses shut down for two to three months and the government permitted a reduction in salaries of up to 40 percent through October 2020 (Al Shurafa 2020).

Transfers into Yemen through one major remittance service, Alkuraimi Islamic bank, were reported to have dropped by 70 percent in March 2020 (Craig 2020). Data collected from interviews with foreign exchange agents in late 2020 confirm that a considerable drop in remittances continued through the year. The modal response from foreign exchange agents on the percentage decline in remittances that they processed due to COVID between September and November 2020 was 45 to 59 percent. Most agents indicated that remittance volumes were increasing again in late 2020, but had not yet returned to normal (CCY 2020a, 2020b, 2020c).

In this policy note, we report on the results of simulations of the effect of the drop in remittances on the Yemeni economy in 2020 using a Social Accounting Matrix (SAM) multiplier model of Yemen's economy. We do not include other economic channels through which the pandemic may have impacted the Yemeni economy, such as through decreases in foreign aid, lowered oil export prices, movement restrictions, and lost productivity from COVID illness, only considering remittances.

\section{Model assumptions}

Household income and consumption is affected both directly and indirectly by lower remittances. First, lower transfers from abroad directly reduce households' disposable income for consumption. For simplicity, we use a model with a constant marginal propensity to consume for each household type. Because some income goes to taxes and savings, the change in consumption expenditure is slightly lower than the full decline in remittances. Second, this change in expenditures and decrease in demand for goods has indirect effects on the wider economy as domestic firms adjust their production. These indirect effects depend on household spending structures, commodity import shares, and intermediate input linkages. Together, these structural characteristics determine the extent of sectoral contraction and the level of income losses in the agricultural, industrial, and services production sectors.

The direct effect is measured by the remittances losses reported for Yemen together with information on personal tax rates and household savings rates structure as given in the Yemen SAM for 2014 (Raouf et al. 2019). To make the results more applicable to Yemen in 2020, we rescale the 2014 SAM using the 2019 Yemen GDP, except for remittances, which are scaled to equal 13 percent of 2019 GDP, as estimated by the World Bank (World Bank 2021). For the estimation of indirect effects, we use the SAM-based multiplier model (see Appendix).

We model an 80 percent decline in remittance volumes. As the multiplier model is a linear model, the impacts of a higher or lower decline would change in direct proportion to the size of the decline.

\section{Impacts on GDP by sector}

As a result of the drop in remittances, Yemen's real GDP for 2020 is estimated from our model scenario to decline by 8.5 percent (Figure 1). The impacts on the economy are fairly evenly 
distributed across sectors. The agriculture sector is modeled as declining more than 9 percent and the industry and service sectors by more than 8 percent. The agriculture sector, the industry and the services sectors represent 19, 20, and 61 percent of the Yemeni GDP in 2019, respectively. So, while the agricultural sector is the most affected in percentage terms, the largest absolute decline appears in the services sector.

Figure 1: Estimates of change in sectoral GDP for Yemen during 2020, percentage change from 2019

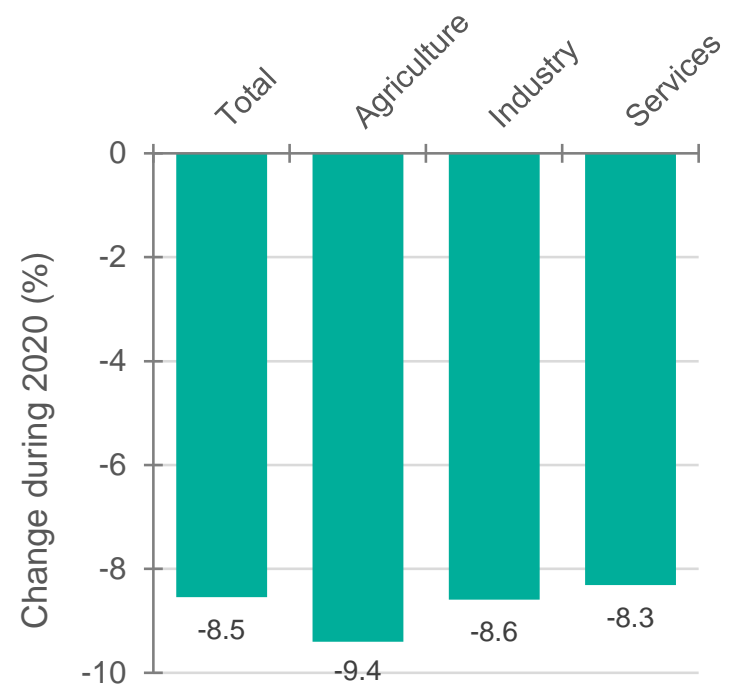

\section{Figure 2: Estimates of COVID 19 impacts on Yemen's agri-food system, percentage change from 2019}

Source: COVID-19 Yemen multiplier model

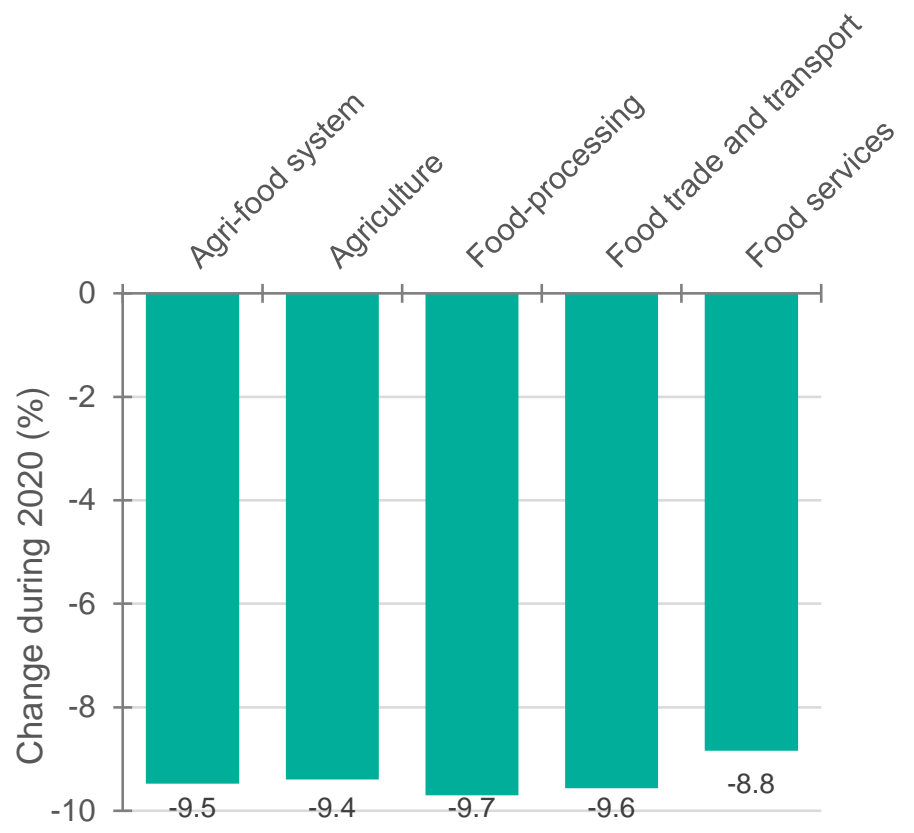

The reduction in the services sector is dominated by losses in wholesale and retail trade and in transport and communication - lower household demand has a strongly adverse impact on trade and transport since it affects all value chains. The negative impact on services is also driven by lower demand for health and education services. These demand shortfalls contribute more than 40 percent to the 8.5 percent decline in Yemen's GDP.

The fall in industrial and manufacturing output is due to lower household demand and changes in the demand for intermediate inputs as well as indirect effects via the many strong forward linkages in the Yemeni economy, especially for food processing, trade, and transport.

\section{Impact on agriculture and agri-food system}

Looking in detail at the impacts on the agri-food system, we see that that the agri-food system as a whole declined by 9.5 percent (Figure 2). While all food sectors are affected, the greatest economic damage occurs in food processing, including grain milling and coffee processing, with estimated losses of 9.7 percent (Figure 2).

Unpacking the over 9 percent drop in total agricultural value-added, the modeling results show a slightly higher decline in the production of cereals, pulses and oilseeds, root crops, and fruits and vegetables than for other agricultural activities (Figure 3, left-hand chart). The contraction of foodprocessing sectors is largely attributable to direct demand effects resulting from lower household expenditures, since these sectors primarily produce final goods, rather than primary or intermediate goods. Impacts in cereal milling are highest (Figure 3, right-hand chart). 
Figure 3: Estimates of change in agriculture and agro-processing GDP in 2020, percent change from 2019
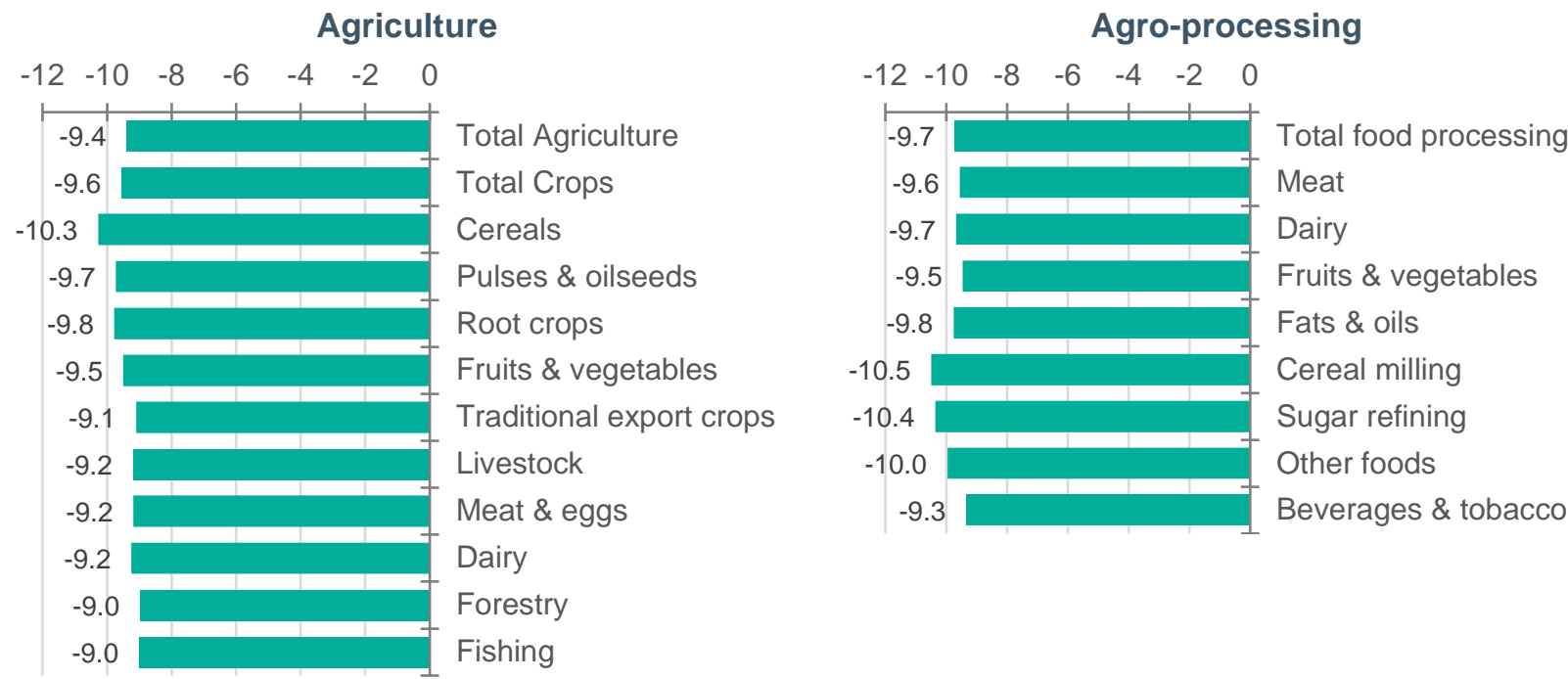

Source: COVID-19 Yemen multiplier model

\section{Impact on employment}

The impact of the COVID-19 induced decline in remittances on employment was mainly driven by job losses in the services sector, which employs 60 percent of all workers (according to the SAM), followed by agriculture, which experienced the largest relative decline (Figure 4). Within the service sector, trade and transport experienced a sharp fall in demand as a result of reduction of almost all value chains. Consequently, workers in this sector were hit hard by the crisis. Sluggish demand for business and health services and real estate activities, for household workers, and in construction, and agriculture also contributed significantly to the decline in employment. It should be highlighted that much of the employment in these sub-sectors is characterized by a high level of informality, as nearly half of the wage workers in them are not covered by the country's social security system.

Figure 4: Estimates of change in employment during 2020, absolute and percent change from 2019, by sector

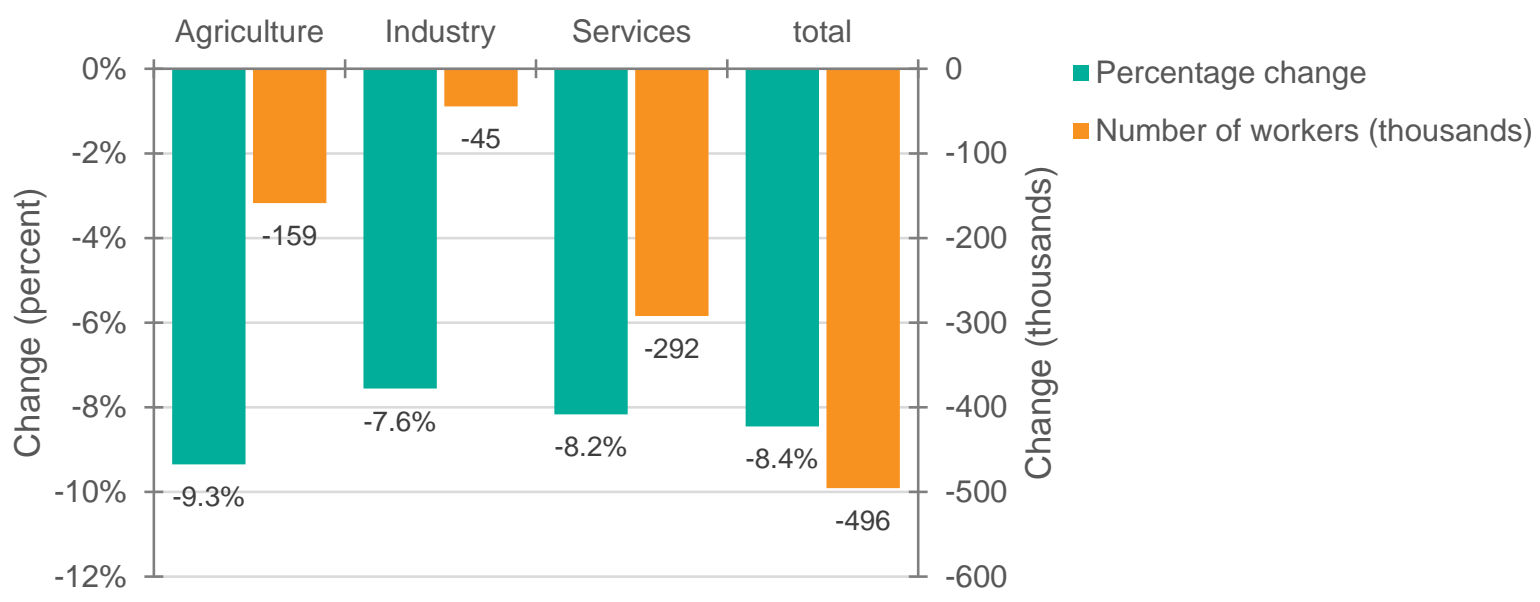

Source: COVID-19 Yemen multiplier model.

\section{Impact on household income}

While all Yemeni households are modeled as experiencing an income loss in 2020 due to COVID-19, disparities between different households are significant. These largely result from the varying role of remittances at different income levels, even as households are more equally affected by indirect 
effects that result from production levels. A comparison of total household income changes in Figure 5 with direct changes resulting from remittances shows that indirect effects resulting from interactions in the broader economy generally add another 2 to 3 percentage points to income losses beyond the direct effect of the loss in remittances. These additional income losses reflect lower factor incomes resulting from the contraction of the agriculture, industry, or services sectors.

Figure 5: Change in household income during 2020, percent change from 2019

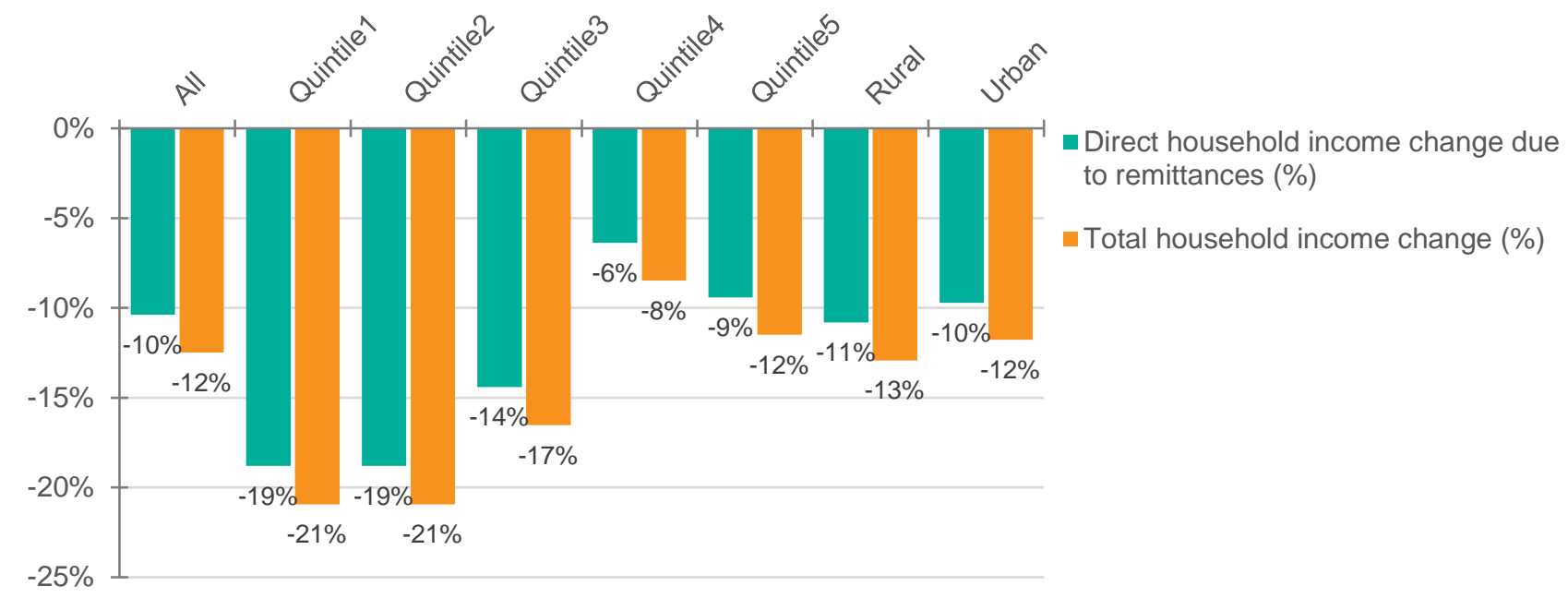

Source: COVID 19 Yemen multiplier model.

Overall, the poorest households, represented by quintiles 1 and 2, are shown by the model as suffering a severe income loss of approximately 21 percent over the year 2020 (Figure 5). Most of their income was dependent on remittances coming from a family member working outside of Yemen. As for the higher income quintiles, the share of income loss due to the decline in remittances is less significant, although absolute income losses are larger.

Rural households were subject to slightly higher income losses compared to urban households (Figure 5). This is both because rural households belong to the poorer segments of Yemeni society with higher shares of remittances income and because they get a larger share of earned income from agriculture and services, which were more heavily affected by lower household consumption.

With the continuation of the war, few direct large-scale mitigation measures against the impact of COVID-19 were implemented in Yemen. Our SAM multiplier modeling results, however, show that considering only lower household remittance income due to COVID-19, there would already be a sizeable adverse short-term impact on economic output and household welfare in Yemen. The magnitude of the longer-term impact of this shock will depend on the internal responses of Gulf countries to the COVID-19 pandemic, on one hand, and on the flow of foreign aid to Yemen designated for both food and health sectors, on the other. 


\section{References}

Al Shurafa, S. 2020. "COVID-19: Saudi Arabia to cut salaries by 40\%," Gulf News, May 4, 2020, https://gulfnews.com/world/gulf/saudi/covid-19-saudi-arabia-to-cut-salaries-by-40-1.1588609488167

Breisinger, C., M. Thomas, and J. Thurlow. 2009. Social accounting matrices and multiplier analysis. An introduction with exercises. Washington, DC: International Food Policy Research Institute.

CCY (Cash Consortium of Yemen). 2020a. September. Remittances Tracker. https://reliefweb.int/sites/reliefweb.int/files/resources/CCY\%20Remittances\%20Tracker\%20September\%202020.pdf

CCY (Cash Consortium of Yemen). 2020b. October. Remittances Tracker. https://reliefweb.int/sites/reliefweb.int/files/resources/Remittance\%20Tracke_November.pdf

CCY (Cash Consortium of Yemen). 2020c. November. Remittances Tracker. https://reliefweb.int/sites/reliefweb.int/files/resources/Remittances\%20Tracker\%20\%20\%281\%29.pdf

Craig, I. 2020. "In Yemen, families suffer as COVID-19 dries up money from abroad." The New Humanitarian. 16 June. https://www.thenewhumanitarian.org/news-feature/2020/06/16/Coronavirus-Yemen-economy-remittances.

MPIC (Ministry of Planning \& International Cooperation). 2018. Yemen Socio-Economic Update, February 2018. Issue 32. Sana'a: Economics Studies \& Forecasting Sector, MPIC. https://fscluster.org/sites/default/files/documents/yseu32_english_final.pdf

MPIC (Ministry of Planning \& International Cooperation). 2019. Yemen Socio-Economic Update, August 2019. Issue 44. Sana'a: Economics Studies \& Forecasting Sector, MPIC. https://reliefweb.int/sites/reliefweb.int/files/resources/YSEU44_English_final.pdf

Raouf, M., J. Randriamamonjy, W. Engelke, T. Al Kebsi, S.A. Tandon, M. Wiebelt, and C. Breisinger. 2019. Regionalized Social Accounting Matrix for Yemen - A 2014 Nexus Project SAM. MENA RP Working Paper 21. Cairo: International Food Policy Research Institute.

Round, J. 2003. "Social Accounting Matrices and SAM-based Multiplier Analysis." In F. Bourguignon and L. A. Pereira da Silva, eds. Techniques and Tools for Evaluating the Poverty Impact of Economic Policies. Washington, DC and Oxford, UK: World Bank and Oxford University Press. ch. 14.

Thurlow, J. 2020. "A standard multiplier model for COVID-19 assessments." Unpublished SAM multiplier model (available upon request). Washington, DC: International Food Policy Research Institute.

World Bank. 2021. "Personal remittances, received (current US\$) - Yemen, Rep." World Bank Open Data. Washington, DC: World Bank. https://data.worldbank.org/indicator/BX.TRF.PWKR.CD.DT?end=2019\&locations=YE\&start=1990\&view=chart 


\section{Appendix - Assessing short-term COVID-19 impacts with a SAM multiplier model}

Social Accounting Matrix (SAM) multiplier models are ideally suited to measuring short-term direct and indirect impacts of unanticipated, rapid-onset demand-side economic shocks, such as those caused by the COVID-19 pandemic. At the heart of the multiplier model is a SAM, an economywide database that captures resource flows associated with all economic transactions that take place in the economy, usually over the course of a financial year. As such, the SAM represents the structure of the economy, showing the relationships between actors, i.e., productive activities, households, government, and external sector, in terms of how they interact and transact via commodity and factor markets. The SAM multiplier model provides a mechanism for estimating the effects of an external shock - typically an exogenous change in final demand for goods and services - on sectoral and national production, factor incomes (wages or rents), and household incomes on the basis of the production, employment, and consumption relationships captured in the SAM.

Apart from the direct production effect in the sector affected by the demand change, other sectors are affected indirectly via changes in demand for intermediate inputs. Additionally, resulting changes in the levels or composition of employment could lead to further changes in household consumption demand. The strength of the multiplier model lies in the fact that the multiple rounds of these indirect effects are fully captured. The more detailed the SAM is in terms of the activities, commodities, and factor and household accounts it includes, the more refined the SAM multiplier analysis is in terms of analyzing the direct and indirect impact pathways and distributional effects of the external shock.

Since this is a short-run analysis period, it is assumed that technical input-output relationships, the input choices of producers, and the consumption patterns of households do not (as yet) change in response to the simulated shock. Such behavioral responses are captured in general equilibrium models, but the anticipated short-term nature of the COVID-19 shock and the likelihood that the economy will return to a "business-as-usual" state once the crisis dissipates over time makes the SAM multiplier framework a more appropriate tool for analyzing this particular shock (Breisinger et al. 2009; Round 2003). Consistent with the short-term nature of the analysis, we assume that net expenditures for households and government, patterns of savings and investment, and international trade are exogenous to the model, i.e. we do not take into account second-round effects on these economic flows.

The Yemen multiplier model is based on a SAM developed by the International Food Policy Research Institute (Raouf et al. 2019). While the SAM itself has a 2014 base-year, multiplier results are applied to national accounts, household income, and population data for 2019 to permit an assessment of the likely impacts of COVID-19 in 2020. This note uses an extended version of the multiplier model that captures sector-level impacts and seasonality in the impacts (Thurlow 2020).

Figure 6 summarizes the underlying conceptual framework of the SAM multiplier model and how it could be used to examine the likely economic impacts of COVID-19. Although the Yemen COVID-19 analysis is focusing on just one external direct impact channel, i.e. inflow of remittances, there are generally both external and internal (domestic) impact channels. External channels include exports and remittances, while the domestic impact channels depend on full or partial lockdown measures. These domestic impact channels might provoke negative effects, such as the closure of restaurants, factories, and commercial shopping centers. They also might induce positive outcomes. especially with regards to the information and communication technology (ICT) and the healthrelated sectors. In the SAM multiplier model, a closure of restaurants, for example, is modeled as a 100 percent loss of restaurants output. Similarly, if textile factories are operating with two shifts instead of three, we would assume a reduction of about 30 percent in the output of the textile subsector. 
Figure 6: Conceptual framework of the SAM multiplier model for the Yemeni economy
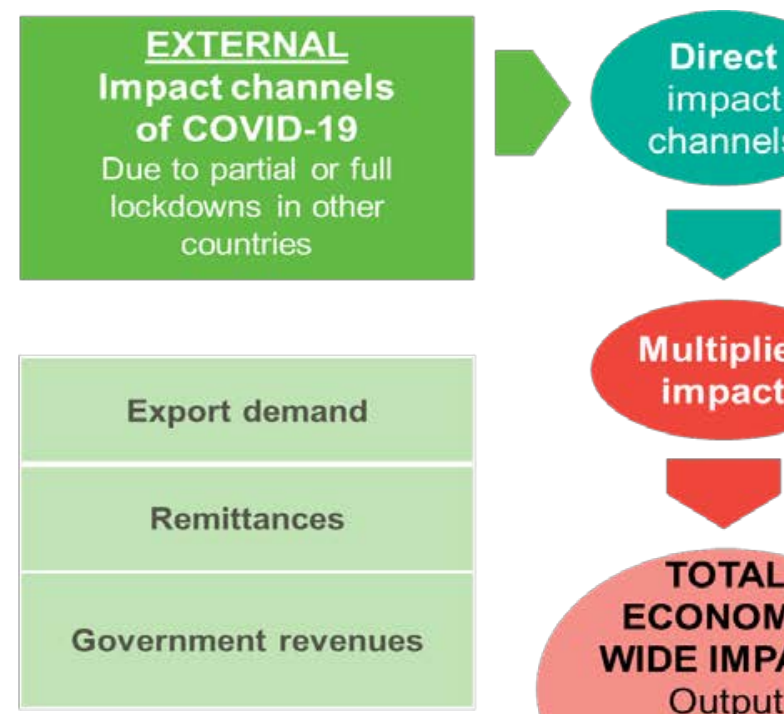

impact

channels
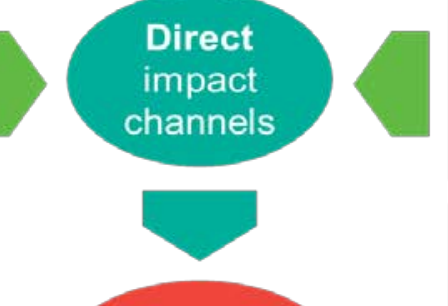

Multiplier

impact

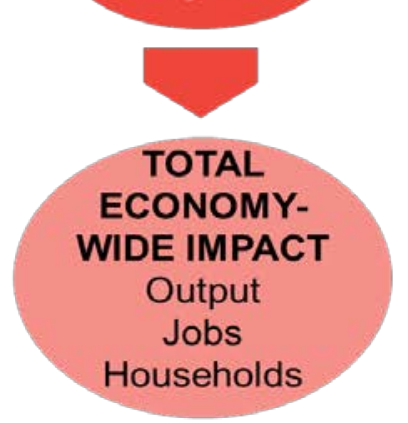

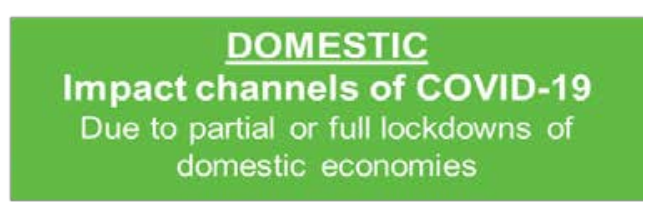

Agriculture Banking, finance \& insurance

Mining \& crude oil Professional \& business services

Manufacturing

Utilities

Construction

Wholesale \& retail

trade services

Transportation, storage \& cargo

Hotels \& food services

Source: Authors.

Both the external and domestic impact channels induce a direct impact on economic activity. However, there are also several rounds of indirect effects. For instance, the closure of restaurants as a result of lower consumption spending induced by lower remittances income would result in sharply reduced demand for food commodities. These are the multiplier effects that are captured by our economy-wide SAM multiplier model. 


\section{ABOUT THE AUTHORS}

Dalia Elsabbagh is a Senior Research Assistant in the Egypt Strategy Support Program (ESSP) of the International Food Policy Research Institute (IFPRI), based in Cairo. Sikandra Kurdi is a Research Fellow in the Development Strategy and Governance Division of IFPRI, working with ESSP. Manfred Wiebelt is a Senior Research Fellow and Professor of Economics (emeritus) at the Kiel Institute for the World Economy, Kiel, Germany.

\section{ACKNOWLEDGMENTS}

We are grateful for excellent comments and support from Clemens Breisinger.

Funding for this study was provided by the International Fund for Agricultural Development (IFAD) under the Agriculture Investment Data Analyzer (AIDA) project and the CGIAR Research Program on Policies, Institutions, and Markets (PIM). 